This is an Accepted Manuscript of an article published by Taylor \& Francis in Women: A Cultural Review on 16 July 2015, available online:

http://www.tandfonline.com/doi/full/10.1080/09574042.2015.1035021

\begin{abstract}
:
This article draws on material from the riot grrrl archives at New York University's Fayles Library to examine the culture of 'zine' production in US riot grrrl communities during the 1990s. After investigating the relationship between the political issues and aesthetic strategies explored by riot grrrl literary producers, I analyse the points of tension arising within the movement which become illuminated by zines' revelatory confessional modes, or what Mimi Thi Nguyen has called riot grrrl's 'aesthetics of access'. I subsequently enquire after the implications for riot grrrl politics of understanding experiences of oppression and transgressive behaviour as cultural commodities. Finally, I go on to trace the commodification of the transgressive feminist gesture in mainstream popular culture and contemporary US online feminist activism.
\end{abstract}

\title{
Biographical information
}

Emily Spiers is a Research Associate at the Department of European Languages and Cultures at Lancaster University. Her doctoral thesis explored modes of popular contemporary feminist writing in the US, Britain and Germany. She is currently researching feminist literary activism in relation to spoken-word poetry.

\section{Keywords:}

Riot grrrl; zines; postmodernism; autofiction; the Internet; transgression; feminism; popular culture 


\title{
'Killing Ourselves is not Subversive': Riot Grrrl from Zine to Screen and the Commodification of Female Transgression
}

\author{
Emily Spiers \\ The twentieth anniversary of riot grrrl's ascendance prompted renewed media and academic \\ interest in the US, UK and Europe (Germany and Austria, in particular), adding to the already \\ substantial body of scholarship on riot grrrl in feminist and Girl Studies. ${ }^{1}$ The international
} media coverage of the incarceration in 2012 of three members of Pussy Riot also instigated debate about radical feminist protest and the possible resurgence of grassroots feminist activism. ${ }^{2}$ In general, the anniversary provided the opportunity to reflect upon the state of contemporary feminism in the cultural contexts mentioned above; but accounts more often refer nostalgically to a lost spirit of radical feminist protest.

Riot grrrl's ascendance can be traced to musicians and zine creators Tobi Vail, Allison Wolfe, Molly Neuman and Kathleen Hanna (founders of the bands Bratmobile and Bikini Kill) and is linked geographically with Washington State and Washington D.C. Historical accounts situate the origins of riot grrrl within a climate of unresolved social tensions, which were reaching breaking point on American soil by 1991. In May that year, a

\footnotetext{
The title quote is taken from Kathleen Hanna zine, April Fools' Day, 1995, Fales Library and Special Collections, New York University Libraries: Johanna Fateman Riot Grrrl Collection, MSS 258, box 1, folder 64, correspondence between Hanna and Johanna Fateman 1994-2000. The riot grrrl collection at Fales Library, opened in 2009, documents the evolution of the riot grrrl movement, focussing on the years between 1989 and 1996. The primary area of collecting is the personal papers of those involved in the creation of fanzines, music and activism. The term 'zine' (derived from 'fan magazine', which became 'fanzine', then 'zine') refers to formally heterogeneous, hand-made graphic and textual productions circulated amongst small groups of people interested in a certain topic, musical group or literary genre. They often include political essays, creative writing, confessional passages and graphic work.

${ }^{1}$ Karren Ablaze!, 'Riot grrrl: Searching for Music's Young Female Revolutionaries', Guardian, 18 March 2013; The Punk Singer, directed by Sini Anderson (opening band films, 2013); Olivia Laing, 'Grrrls Who Wanted More than Just Fun...', Observer, 30 June 2013; Joe Pompeo, 'Original "riot grrrl” Kathleen Hanna meets the press, and this time it's happy', Capital New York, 31 May 2013; Rachel Smith, 'Revolution Grrrl Style, 20 years later', NPR music, 22 September 2011, at www.npr.org/blogs/therecord/2011/09/20/140640502/revolution-girl-style-20-years-later?sc=tw\&cc=share (viewed 4 October 2013). See also, 'Riot Grrrl's not dead: Film- und Projekttage zu 20. Jahre Riot Grrrl', as part of this human world festival 2012 in Vienna; Christian Ihle, 'Who's That Grrrl? Eine Einleitung zu Riot Grrrl Revisited', taz.blog, 2 November 2011, at blogs.taz.de/popblog/2011/11/02/whos_that_grrrl__eine_einleitung_zu_riot_grrrl_revisited/ (accessed 4 October 2013); Katja Peglow and Jonas Engelmann (eds), Riot Grrrl Revisited: Geschichte und Gegewart einer feministischen Bewegung, Mainz: Ventil Verlag, 2011.

${ }^{2}$ Pussy Riot is a Russian feminist punk rock group, three of whose members were incarcerated by the government in 2012 after they performed and filmed a song criticising Vladimir Putin's regime and the Orthodox Church's support of it.
} 
Salvadorian man was shot by a white police officer during the traditional Cinco de Mayo celebrations in the Mount Pleasant neighbourhood of Washington D.C. ${ }^{3}$ Days of so-called 'race riots' ensued, which marked the beginning of a period of civil unrest and protest against ethnically-motivated discrimination in impoverished urban centres across the US,

culminating in the LA riots of 1992. One of the most pervasive origin narratives for the punk feminist movement riot grrrl embeds its emergence in the unfolding of these riots, citing musician Jean Smith's letter to fellow Bratmobile band member Allison Wolfe, in which she wrote: 'We need to start a girl riot'.

Yet it is important to note that the movement was and remains heterogeneous and spatially diffuse. Those involved in the initial stages were ideologically invested in the notion of a girl collective and resisted co-option as figure-heads, instead encouraging girls to create their own music, art, writing and forms of protest. Thus, young women who could not yet play instruments or who had never expressed themselves through the medium of writing picked up a guitar or a pen and 'did it themselves'. Riot grrrl co-opted punk, with its aesthetic discordance and counter-cultural energy, in order to scream feminist protest and give voice to female desire from the stages of venues on the East and West coasts of the US, as well as in Great Britain.

As Mimi Thi Nguyen notes: 'These women in each their own way refused to believe that the avant-garde, the revolution, and the work of art that challenged but also channelled both were only masculine provinces. ${ }^{, 5}$ In their musical and textual productions riot grrrls not only launched an attack against capitalism and consumer culture but also thematised feminist issues such as rape, assault and the physical and psychological abuse of women. In order to

\footnotetext{
${ }^{3}$ The festival constitutes a celebration of American-Mexican relations, and marks a commemoration of the causes of freedom and democracy in the first years of the American Civil War.

${ }^{4}$ Jean Smith, cited in Mimi Thi Nguyen, 'Riot Grrrl, Race, and Revival', Women and Performance, 22: 2-3, 2012, 173-96 (p. 173). Bratmobile was an American band synonymous with the riot grrrl movement; their DIY ethos and punk aesthetics functioned as a template for subsequent riot grrrl bands.

${ }^{5}$ Nguyen, 'Riot Grrrl, Race, and Revival', p. 174.
} 
do so, they drew on the repository of feminist theory developed over the previous two decades, challenging punk's premise that disciplinary power resided only in capitalism and authoritarian state control, as well as confronting the misogynistic tendencies within the punk movement itself.

In their textual undertakings, whether in song lyrics and performance poetry, or the modes most commonly found in zines, such as graphic art, poetry, short stories and confessional autofiction, riot grrrls demonstrated an acute awareness of how identities arise from a nexus of social determiners such as gender, sexuality, class and race - and how those factors impact upon the individual's encounter with authoritarian power structures. Drawing on one of the central tenets of second-wave feminist thought, riot grrrls linked the personal with the political, connecting individual lived experience to inequality and injustice perpetuated by dominant power structures. As Riot Grrrl Manifesto (1991) states, riot grrrl exists 'BECAUSE viewing our work as being connected to our girlfriends-politics-real lives is essential if we are gonna figure out how what we are doing impacts, reflects, perpetuates, or DISRUPTS the status quo'. 6 This self-reflexive gesture characterises much riot grrrl engagement. Writing for an anthology of riot grrrl creative work which went unpublished, Nina Aron and Beth Blofson, for example, claim that the movement constituted a 'call to arms, encouraging girls to revolutionize themselves and redefine themselves as punks, as girls, as individuals'. ${ }^{7}$ In a zine dedicated entirely to the issue of addiction (substance abuse was rife in the punk scene), Kathleen Hanna, singer in the band Bikini Kill and later Le Tigre,

\footnotetext{
${ }^{6}$ This zine from 1991 is purported to have originated from the collaboration between members of the bands Bratmobile and Bikini Kill, whose aim was to spread a 'Revolution Girl Style Now'.

${ }^{7}$ Fales Library and Special Collections, New York University Libraries: Sheila Heti Riot Grrrl Collection, MSS 366, box 5, folder 8, Nina Aron and Beth Blofson, 'What a Riot!', in Poised: An Anthology of Writing and Art by Young Women, 1996. Random House dropped the anthology late in the editing stages when they realised that the actual product, with its overall tone of defiance and protest, defied their expectations of young girls' writing. They also calculated that the demographic constituting the anthology's intended readership would entail that they would make a financial loss on the project.
} 
makes a connection between (her own) addiction issues and the inequities inherent in wider social structures. She writes:

I am interested in the intersections between oppression and addiction cuz I think it is entirely political and specific WHO is most suceptible [sic] to certain addictions, and, I also think internalised oppression (think self hate) and emotional/spiritual bankruptcy has everything to do with it. Making these connections, like between capitalism and addiction, or sexual/physical abuse and addiction, or sexism and addiction, HELP [sic] KEEP ME SOBER. ${ }^{8}$

In the first part of this article I explore the nomadic community forged by the circulation of zines, which provided an alternative and complementary locus of riot grrrl engagement from the radical public performances enacted by riot grrrl bands. ${ }^{9}$ These amateur publications initially functioned as fan magazines created by female punk enthusiasts involved in the music scene, but quickly became an interactive forum for radical political debate as well as for subversive creative writing across genres by young self-identified riot grrrls. I go on to examine the drawbacks of the aesthetics of intimacy favoured in riot grrrl zine productions, comparing confessional modes of zine writing with other aesthetically complex and experimental fictional undertakings. Finally, I trace the development of the transgressive feminist gesture from those early riot grrrl textual productions to its subsequent uptake and commodification online and in the music industry, enquiring after the relationship between the economics of production and the critical impact of the cultural product in relation to postriot grrrl popular culture.

\section{Authenticity, Intimacy and Oppression in Riot Grrrl Zine Culture}

Riot grrrl fanzines - or zines — often included confessional autofiction, satirically humorous graphic art, epistolary exchange between creator and readers and discussions of gender and nascent queer theory. Members of this nomadic community (ranging on average between

\footnotetext{
${ }^{8}$ Hanna, April Fools' Day.

${ }^{9}$ At this time, zines would be passed around between groups of friends, or left in anonymous public spaces where women outside the scene might discover them. In order to receive a zine, or to order the next number in the series, readers would send postage costs and their address to the zine's creator. Zine creators often adopted pseudonyms, as personal prestige was considered secondary to the sense of collective their zines promoted.
} 
thirteen and twenty-five years old) often experienced themselves as marginalised and alienated from mainstream society, from the cultures in which they were physically, socially and geographically embedded. The mediated and mediating material culture of zines, which facilitated text-based, consciousness-raising encounters between zine and reader(s) that cut across regional and even national boundaries, engendered a sense of intimate solidarity (or to use riot grrrl parlance 'girl love') amongst readers. This sense of intimacy was enhanced by the confessional tone dominating riot grrrl textual productions, exemplified by the above quote from Hanna, in which she reveals her genuine addiction.

Social and political change was linked to an accrual of knowledge of oneself and of the other. Aron and Blofson, for example, observe that riot grrrl 'placed an emphasis on communication as a vital force, encouraging education through interaction' ${ }^{10}$ Lack of knowledge was therefore understood to form the basis for discrimination of all kinds, which engendered in zines what Mimi Nguyen calls an 'aesthetics of access'. ${ }^{11}$ Understanding the experiences of the other as well as investigating one's own complicity in perpetuating discrimination accumulated an ethical dimension, for example, in this second point from the manifesto:

BECAUSE doing/reading/seeing/hearing cool things that validate and challenge us can help us gain the strength and sense of community that we need in order to figure out how bullshit like racism, able-bodieism [sic], ageism, speciesism, classism, thinism, sexism, anti-semitism and heterosexism figures in our own lives.

Successful intersubjective relations, therefore, based on knowledge and reaching across 'isms', constituted the central impulse of the riot grrrl ethos. But true knowledge could only be imparted if texts attained genuine authenticity. The revelatory trope thus features heavily in much riot grrrl writing: grrrls write about their most traumatic experiences, whether that is abuse, psychological instability or other mental-health issues, self-harm or addiction. The

\footnotetext{
${ }^{10}$ Aron and Blofson, 'What a Riot!'.

${ }^{11}$ Nguyen, 'Riot Grrrl, Race, and Revival', p. 174.
} 
emphasis riot grrrl placed upon the revelation of true, lived experience as a means of assuring authenticity evinces a continuity with one school of second-wave feminist thinking in which realistic writing, and above all, autobiography, featured as the ideal mode of consciousnessraising feminist writing. The confessional mode, in particular, fostered a culture of preemptive self-critique or elective submission to public shaming, in which writers would expose themselves as 'flawed, processual beings [...] or, in the name of intimate love, allowed themselves to be publicly critiqued for their entitlements. Public shame, whether pursued through rigorous self-critique or delivered through the letters of an interlocutor, served as evidence of accountability'. ${ }^{12}$ In April Fools' Day, for example, Hanna writes:

In writing this stuff I have had to think a lot about how to share information without acting all bossy or being condescending. [...] Just cuz I'm an addict/alcoholic (whatfuckin-evah) doesn't mean I think I can speak for everyone in terms of addiction. It seems to me that each addict functions within his/her own context in terms of race, gender, location, class, personality, access, etc.... So it would be ridiculous for me to try and write a "manifesto" or a "universal account" of how addiction works. ${ }^{13}$

Here Hanna's 'etc.' functions to pre-empt exposure to external critique that she speaks from a privileged and universalist position as a white woman, but importantly arrives after Hanna's revelation of her experience, indeed her expertise, in relation to addiction (her casual selfironisation '(what-fuckin-evah)' should be viewed similarly as a pre-emptive strike to evade accusations of assumed authority, self-righteousness and privilege). The culture of privilegechecking fostered by riot grrrl zines results, as Nguyen notes, in a 'troubling politics' in which traumatic experience reinterpreted as the result of systemic oppression 'enhances an authentic marginality, translating experience into expertise' ${ }^{14}$ In a later essay on her decision to leave the riot grrrl scene, for example, Hanna recounts the self-imposed transformation of one of her riot grrrl colleagues from 'white middle class and straight' to a 'working class lesbian who, of all things, identified herself as "black". Hanna goes on: "[d]ay by day I

\footnotetext{
${ }_{12}^{12}$ Nguyen, 'Riot Grrrl, Race, and Revival', p. 174.

${ }_{13}^{13}$ Hanna, April Fools' Day.

${ }^{14}$ Nguyen, 'Riot Grrrl, Race, and Revival', p. 179.
} 
watched as Jenny became more and more "oppressed". It actually felt like she'd thrown herself into a Miss America pageant in reverse. I.e. Instead of scrambling for a gold crown, she was scrambling for the title of Miss Least Enfranchised'. For Hanna, it was as if 'white middle class straight people [feel] entitled to everything, even other people's oppression' ${ }^{15}$

Here lies a further reason for Hanna's judiciously placed 'etc.' at the end of the list of possible identity determiners in the above quotation. The ultimately unsatisfactory if wellintentioned catch-all ellipsis recalls Judith Butler's quibble, expressed in Gender Trouble (1990), with feminist identity politics which seek, but invariably fail, to encompass a fully situated subject. ${ }^{16}$ Furthermore, Nguyen has argued that the aesthetics of access practiced by white middle-class riot grrrl activists pivoted upon a sentimental impulse which created an illusory 'intimate public' in the sense used by Lauren Berlant. ${ }^{17}$ In Nguyen's view, this desire for, and belief in, successful intersubjective intimacy entailed that in fact change was conceived of "narrowly as the adjustment of the individual subject - recalibrating her capacity for love or shame, for instance - to the structural determinations that constitute the historical present', i.e. race, class, gender, sexuality 'etc.'. This adjustment is less based on actual intersectional encounters i.e. really 'knowing' the, in this case racialised, other and more in calibrating the individual to appear 'good' i.e. by acknowledging, and seeking to modify, their privileged positionality. This strategy, according to Nguyen, not only reifies those determiners, like class and race, but also registers 'how neoliberalism and its emphases on the entrepreneurial subject shapes even progressive or feminist adjustments to [...] structural determinations.' According to Nguyen, the development of an ideal intimacy was

\footnotetext{
${ }^{15}$ Fales Library and Special Collections, New York University Libraries: Johanna Fateman Riot Grrrl Collection, MSS 258, box 1, folder 64, correspondence between Hanna and Johanna Fateman 1994-2000, Kathleen Hanna, 'When the Words that once Liberated You Become Bars on Yr Cage - random notes on political depression'.

${ }^{16}$ Judith Butler, Gender Trouble: Feminism and the Subversion of Identity, 3 edn, New York and London: Routledge, 2006, p. 196.

${ }^{17}$ See Lauren Gail Berlant, The Female Complaint: The Unfinished Business of Sentimentality in American Culture Durham, N. C. and London: Duke University Press, 2008.
} 
'confounded' by the question of race in riot grrrl, when white middle-class activists were forced to confront their own complicity in perpetuating racist power structures, and to acknowledge that their desire for knowledge or intimacy with the racialised other might perpetuate an coercive imperialist logic. ${ }^{18}$ For example in Ramdasha Bikceem's fourth issue of GUNK, she addresses the lack of racial diversity in riot grrrl and the matter of oppressionappropriation which not only ignored the genuine plight of the racialised other but functioned to ossify within language and thus in consciousness the discriminatory structures ostensibly intended as the target of riot grrrl. Bikceem is worth quoting at length as her comments summarise the problematic at the centre of riot grrrl:

I used to laugh at this whole white bread punk rock scene, but now I'm not laughing as much as getting more annoyed. I swear every punk show I go to I'm usually the only person of colour in the joint and nobody seems to even question this or even seem to mind. I think my friend Beth was telling me that somebody said that punx [sic] were the "white niggers". What exactly does this mean? I guess it means that punx, like African Americans often reflect what alot [sic] of people don't want to see. They don't want to see the results of their oppressive society. Punx are revolting against a society that has repressed personal expression, which has intern [sic] resulted in the way alot [sic] of them (us???) dress and act etc.... Whereas in the case of African Americans their (our???) oppression has resulted in poverty, lack of education, and low selfimages. But what this concept of "white nigger" fails to realize is that white punx couldn't possibly come close to the stigma that is attached and associated with African Americans. White kids [...] can get away with having green mohawks [sic] and pierced lips 'cause no matter how much they deviated from the norms of society their whiteness always shows through. ${ }^{19}$

Thus zine culture in riot grrrl encouraged a tendency in some activists to brandish their credentials as marginalised subjects in order to gain credibility in the scene, which as I have shown generated rancour amongst those riot grrrls speaking from racialised or otherwise 'other-ed' positions. The cultural capital accrued through the assertion of disenfranchisement often became augmented by the exposure of the psychological consequences of oppression, understood by the zine creator as constituting a vital and cutting-edge violation of social

\footnotetext{
${ }^{18}$ Nguyen, 'Riot Grrrl, Race, and Revival', p. 180.

${ }^{19}$ Fales Library and Special Collections, New York University Libraries: Ramdasha Bikceem Riot Grrrl Collection, MSS 354, box 5, folder 23, Bikceem, GUNK \#4, 1993.
} 
taboos. ${ }^{20}$ In the last edition of her zine Alien the creator, Whitney, reveals and reviles the practice of translating traumatic experience into cultural capital: 'The perpetuation of craziness is disguised in art, if I were to tell you I was cured (gasp!) you wouldn't read on... (-) fuck you $(-)$ if i were to say i cut myself \& my daddy hit me to smithereens you'd ask me when is the next issue coming out. You are reading and I am writing THE COMMODITY OF CRAZINESS in punk'. ${ }^{21}$ This is perhaps why Hanna, in 1995, chose to create a zine based on addiction. She recognised the developing correlation between oppressive dominant social structures, the (sub-)cultural capital linked to marginality and processes of selfdestruction: 'Recovery, to me, is about stripping my addictions of their false sense of glamour + rebelliousness in order to expose how they actually function in my life. [...] Like there are lots of reasons why the people who profit most from "THE AMERICAN WAY" would love to watch those of us who recognise it for the sham that it is DESTROY OURSELVES. ${ }^{22}$

It might be useful to recall at this point Lynne Layton's contention, made in 1995, that trauma, and the consequent subject-splitting it may induce, had at that time become postmodernism's dominant mode. ${ }^{23}$ Hanna argues in a late essay that the 'mainst[r]eam has effectively appropriated certain tenets of post-modernist thought' so that now it is 'just another ruse' making her and others feel 'permanently House of Mirrors'd', indeed 'making certain people feel insane or lost'. ${ }^{24}$

While it would be a mistake to read the textual productions of riot grrrls as mere symptoms of a culturally pervasive theoretical turn, or alternatively as unreflexive, selfindulgent outpourings, many riot grrrls did familiarise themselves with theoretical writing of

\footnotetext{
${ }^{20}$ Here I draw on Bourdieu's notion of cultural capital developed in Pierre Bourdieu, Distinction: A Social Critique of the Judgement of Taste, London: Routledge \& Kegan Paul, 1984.

${ }^{21}$ Whitney, Alien, 1997, cited in Nguyen, 'Riot Grrrl, Race, and Revival', p. 179.

${ }^{22}$ Hanna, April Fools' Day.

${ }^{23}$ Lynne Layton, 'Trauma, Gender Identity and Sexuality: Discourses of Fragmentation', American Imago, 52: 1, 1995, 107-25 (pp. 107-8).

${ }^{24}$ Fales Library and Special Collections, New York University Libraries: Johanna Fateman Riot Grrrl

Collection, MSS 258, box 1, folder 64, correspondence between Hanna and Johanna Fateman 1994-2000, Hanna, 'POSTMODERNIST DISCOURSE AS TRANSMUTATED THRU THE TELEVISION'.
} 
all kinds, evidenced not just by the zines, but by accounts of discussions that took place amongst members of the riot grrrl 'chapters' that arose across the US in the early 1990s and during the conventions that subsequently took place. Kathleen Hanna's later essays, in particular, demonstrate uneasiness with the poststructuralist and postmodern theories informing her and others' initiation into riot grrrl:

Aaaaah the '90s, a time when it actually seemed more progressive (and sexy) to be a barely functioning skitzophrenic than to have a viewpoint one could act from. Sure I know my "inner voice" is shaped by my race, my class, my gender and my citizenship, I also acknowledge that I am an ever changing person and not a static identity. But I am angry with the "post modernist" shit I learned (right about the time I started to think I had an identity in the first place) that told me having one was strictly akin to being a colonizer, a racist or male identified. That is a theoritcal [sic] trap I'd happily see conservative white males plunge into never to return but I just can't afford to wade thru that bullshit for the rest of my life. ${ }^{25}$

One cannot know for sure what theoretical works in particular Hanna refers to in this excerpt, but she has spoken publicly about her admiration for Kathy Acker's fiction and essays.

Indeed, she met the writer at a poetry performance and discussed her work with her, finding parallels between her own work and methodology and the work of the then established author. ${ }^{26}$ Acker, in turn, has been dubbed a 'riot girl ahead of her time'. ${ }^{27}$ Archive material from Hanna's contribution to the Fayles Library riot grrrl collection, for example essays in which she embeds herself in the narrative reading a work by Acker, or the newspaper cutting of Acker's obituary, provide credence to the suggestion that Hanna may have sought out the theoretical sources Acker draws on in her fiction and essays, such as Jacques Derrida, Jean Baudrillard, Michel Foucault, and Gilles Deleuze and Félix Guattari, in particular. Taking Hanna's assessment of the psychological effects of reading postmodern and, presumably,

\footnotetext{
${ }^{25}$ Hanna, 'When the Words that once Liberated You'.

${ }^{26}$ Fales Library and Special Collections, New York University Libraries: Lucy Thane Riot Grrrl Collection, MSS 287, 287.0027 (media), Kathleen Hanna interview, documentary footage of Bikini Kill concerts in Sheffield and Leeds, 13 March 1993, 12:08.

${ }^{27}$ See C. Carr, 'The Legacy of Kathy Acker, Theoretical Grrrl', Village Voice, 5 November 2002, p. 49.
} 
poststructuralist theory, into account, her and others' engagement with this discourse nevertheless yielded compelling aesthetic results.

\section{The Textual Politics of Zine Writing}

As previously mentioned, zines are heterogeneous multimedia productions. Interspersed between what I have called autofictions, or the confessional passages recently discussed, zines often contain radically experimental creative work, both textual and graphic, using cutand-paste techniques and collages to create meaningful juxtapositions. These creations attest to the self-reflexive and strategic writing practices exercised by the most accomplished riot grrrl zine creators. They demonstrate the capacity for what Hanna calls 'writing strategically about a "subject" that is not outside myself" ${ }^{28}$ The Canadian zine creator Sheila Heti's heteroglossic Brillantine, for example (created when she was eighteen), encompasses a snatch of absurdist theatrical dialogue, fantastical short stories, whose meiotic tone and demotic register enhance their grotesquery, satirical cartoons, poems, and a mock interview with a fictitious, egotistical male model entitled 'A Portrait of the Artist as a Young Stallion'. The works emerge from a deeply political impulse, engaging in intertextual dialogues with canonical texts of literary history (as 'A Portrait' demonstrates) as well as the feminist movement in order to critique white-male privilege and strands of contemporaneous feminist thinking. The short story 'I am Woman, Hear me Scream Rape' modifies the title of that famous women's movement anthem to critique some women's misuse of growing social awareness of date rape; the poem entitled 'Lipstick' traces the thought processes of a young woman excited to wear makeup for the first time. Yet the poem ends with a sudden political thrust: 'Of course now I smell like a whore./Lipstick smells thick and what's thicker than a whore?' This poem is juxtaposed with a cut-and-paste excerpt from Henry Miller's Under the Roofs of Paris (1941), in which a graphic and disturbing gang-rape scene takes place narrated

\footnotetext{
${ }^{28}$ Hanna, April Fools' Day.
} 
from one male perpetrator's view point. The contrast in perspective and tone between the two pieces creates an implied critical narrative of its own: the girl in 'Lipstick', due to her choice to begin wearing makeup, becomes 'fair game' for male sexual predators (viz. a 'whore') and slides down a slippery slope of logic to become the lifeless object of a gang rape, the piece of flesh evoked by the name of the lipstick in the poem: 'Hint of Flesh. ${ }^{29}$

The question of sex and, in particular the sex industry, took a prominent place in riot grrrl discourse. Nguyen has argued, for example, that some riot grrrl feminists' decision to work in the sex industry as a transgressive, 'confrontational act', offended poor or criminalclass women who were economically dependent on such work. ${ }^{30}$ No doubt in the spirit of that debate Kathleen Hanna sent a photocopy of Mary Gaitskill's short story 'Something Nice' (from the collection bad behavior, published in 1988) to fellow band member Johanna Fateman at some point between 1994 and 2000. The tale recounts the experiences of a middle-aged, married man during a period of visiting one particular new and inexperienced prostitute working in a New York brothel. The man fantasises about potentially dating the girl in the outside world, but realises the intimacy he thought they shared was a self-delusion when he sees her by chance in a café discussing her attempts to find a decently-paid job in the art world with a friend; she ignores her ex-client. The presence of the photocopy amongst the varied correspondence between the two riot grrrls is significant because it lies alongside an essay on Lizzie Borden's film, Working Girls (1986), a sympathetic portrayal of prostitution as an economic choice. Furthermore, Hanna's riot grrrl paraphernalia contain an essay of her own on prostitution in which she critiques Andrea Dworkin's prohibitive stance on the sex industry. Hanna met Dworkin in 1991 at a time when the former was working as a stripper, a

\footnotetext{
${ }^{29}$ Fales Library and Special Collections, New York University Libraries: Zan Gibbs Riot Grrrl Zine Collection, MSS 364, box 1, folder 20, Sheila Heti, Brillantine, approx. 1996. Heti has gone on to be a well-respected novelist and short-story writer, known predominantly for her autofiction How Should a Person Be? (2010).

${ }^{30}$ Nguyen, 'Riot Grrrl, Race, and Revival', p. 179.
} 
choice she claims she made for economic reasons. ${ }^{31}$ Draft manuscripts of Hanna's experimental writing demonstrate that she, like Mary Gaitskill and Kathy Acker, drew on her experiences in the sex industry in her creative work. It is unclear whether Hanna had read bad behavior before this time, but the text - at whatever time she encountered it - clearly resonated with her own writing practices on a thematic level. In terms of their form and interest in language as both a determiner and challenger of identity, Hanna's experimental prose narratives exist in a dialogic relationship with Kathy Acker's fiction. These prose fragments also negotiate similar thematic terrain: the idea of sex as a commodity ('When [...] a fuck is transposed onto survival in the figure of dollar signs'); violent abuse and incest ('My hands cupped my ears when you hit my sister when you fucked her with yr [sic] fists and i [sic] pretended not to notice because looking opened up the possibility that i'd be next') and desire ('desire, my desire, is not allowed within this economy'). ${ }^{32}$

In the following passage, which is reminiscent of Acker's disjointed, paratactic descriptions of coitus, desire which is not enacted on the speaker's terms is likened to a cold military encounter with death. The narrator speaks to her lover (the first 'you') but the second 'you' may be glossed as representing Acker, whose fictions are littered with the metaphorical conflation of sex, death, hell, and the dyad of pleasure and pain:

(i fuck you like a soldier looks at a dead animal) You said (a girl said) you said that their is the place in fucking that is like hell, the way you imagine hell. It's the moment that is always their on the other side of his/her eyes where you are nothing but the word, dick or pussy and there seems to be nothing but the edge of bliss and the edge of death and our bodies skating along the edge of this. ${ }^{33}$

The inability to access the lover's consciousness despite physical intimacy resembles Acker's 'threshold' encountered during sex, where you must '[c]ommit yourself to not-knowing.' All

\footnotetext{
${ }^{31}$ Fales Library and Special Collections, New York University Libraries: Kathleen Hanna Papers, MSS 271, box 1, folder 25, Hanna, 'Essay' and 'Customers', date unknown.

${ }^{32}$ Fales Library and Special Collections, New York University Libraries: Kathleen Hanna Papers, MSS 271,

box 1 , folder 25, Hanna, un-named prose piece, date unknown.

${ }^{33}$ Hanna, un-named prose piece.
} 
that is available are '[r]ed eyes' which 'stare down on top of my eyes. ${ }^{34}$ In Hanna's piece, the speaker's inability to achieve psychological intimacy with her lover combined with the corollary placed around her own desires manifests itself in the sexual act being translated into a language that is not her own: 'you are nothing but the word, dick or pussy'. Speaking and being spoken through an ostensibly foreign language echoes Acker's observation about her central protagonist in Don Quixote: Which Was a Dream (1986): 'BEING BORN INTO AND PART OF A MALE WORLD, SHE HAD NO SPEECH OF HER OWN. ${ }^{35}$ Yet, like many of Acker's protagonists, in particular Janey in Blood and Guts in High School, the narrator rebels against this language and attempts to 'write down her life' ${ }^{36}$ She avers that 'the best place to start was paper because the only way i could destroy you [the incestuous father-figure/male lover] was by taking back language' ${ }^{37}$

While I agree with Nguyen's assessment of the troubling aspects inherent in riot grrrl's aesthetics of access, especially its role in the alternating elision and reification of racialised power structures, it is vital to recognise zine work and other riot grrrl creative writing as heterogeneous and, importantly, mediated. Nguyen's analysis does not pay enough attention to the ways in which confessional passages (which I would argue are anyway selfreflexively constructed texts) often lie alongside experimental creative pieces, either textual or graphic, which offer their own commentary on the 'autobiographical' aspects of the productions, as I have shown with Heti's work. Diana Fuss's insightful argument that the 'problem with attributing political significance to every personal action is that the political is soon voided of any meaning or specificity at all, and the personal is paradoxically depersonalised', informs my contention that riot grrrl creative (as opposed to confessional) work can be viewed as channelling the personal into genres - fiction, poetry, graphic art-

\footnotetext{
${ }^{34}$ Acker, Great Expectations, in Acker, Blood and Guts in High School:Plus Two, London: Picador, 1984, p. 235.

${ }^{35}$ Acker, Don Quixote: Which Was a Dream, London: Paladin, 1986, p. 58.

${ }^{36}$ Acker, Blood and Guts in High School, p. 65.

${ }^{37}$ Hanna, un-named prose piece.
} 
that avoid that very collapse by moving the personal into the realm of imagination, where the political dimension may be preserved and extrapolated on the reader's own terms. ${ }^{38}$

In general, riot grrrl texts connote constructed performances which cannot be read at face value but as modes of politicised self-fashioning. They function to deconstruct but also construct the creator's identity. The confessional passages work to pick apart layers of social conditioning, encompassing privilege-checking and public self-shaming (as Nguyen notes), as well as traumatic and oppressive experiences, but the act of zine construction, of creating a multi-media, self-reflexively composed narrative constitutes a strategy of identity construction, which, as Hanna recognises above, was threatened not only by conventional patriarchal forces, but by strands of pervasive critical theory. Riot grrrl textual productions seek to create a nascent feminist consciousness through and despite discursive forces which posit the dissolution of the coherent subject per se, as Hanna observes, '...that's where writing comes in'. ${ }^{39}$ (It is perhaps especially in her work that the tension between the desire for the whole, recovered self and the work of deconstructing the self becomes apparent.) Bikceem, too, claims: 'I think doing this fanzine in a way saved my life. [...] During high skool this fanzine was my only creative outlet. ${ }^{40}$ Zines and other riot grrrl productions do not merely constitute a kind of therapy, but provide a forum for creative self-expression in narrative form. As Kathy Acker observes: '[i]t's a common belief that something exists when it's part of a narrative. Self-reflexive consciousness is narrational. ${ }^{, 41}$ Heti recognised the capacity for constructive and politically efficacious creativity in young riot grrrls' writing when she appealed for contributions to the riot grrrl anthology: '[w]e need, as a collective, to promote the art created by young girls. [...] We can be political, we can be intelligent and

\footnotetext{
${ }^{38}$ See Diana Fuss, Essentially Speaking: Feminism, Nature and Difference, London: Routledge, 1990, p. 101.

${ }^{39}$ Hanna, April Fools' Day.

${ }^{40}$ Bikceem, Gunk \#4.

${ }^{41}$ Acker, Great Expectations, p. 204.
} 
edgy and emotional without the requisite angst etc... ${ }^{42}$ Hanna recognises the processual nature of this project when she observes that '[1]ike the recovery process itself, this writing will never REALLY be completed' ${ }^{43}$

\section{From Riot Grrrl to Soft-Punk: Mainstreaming Female Transgression}

Riot grrrl, despite the fact that almost all commentators declare the movement to have dissolved by 1996, never was 'completed'. It is certainly the case that as the 1990s progressed the movement was exposed, justifiably, to increasing critique from within, which challenged the blind spots of white middle-class riot grrrls, in particular. It is tempting therefore to round off the narrative with rhetoric familiar from popular accounts of the second wave in the late 1980s: with references to sectarianism and in-fighting around issues of race, class and attitudes towards men. Yet that would be to establish an inaccurate and oversimplistic periodisation of feminist history which functions to contain the long-term resonances of the movement and to ignore the role that the media and consumer culture played in appropriating riot grrrl as a profitable commodity within mainstream culture.

In riot grrrl's early days, media interest in the politics and protest of the movement soon segued into trivialising, feminising and often downright condescending discussion of the protagonists' punk fashion sensibilities. ${ }^{44}$ Of course, initial media coverage also helped to attract many young girls to the movement, but in order to ensure integrity and to protect the local, DIY ethos of the movement, many riot grrrls, including the band Bikini Kill, called for a media boycott in 1992. This decision piqued the press's interest and more coverage ensued. $^{45}$

\footnotetext{
${ }^{42}$ Heti, Brillantine.

${ }^{43}$ Hanna, April Fools' Day.

44 'A movement begins in a million pink bedrooms', LA Weekly, 10-16 July 1992, pp. 19-28, here p. 20; 'Meet the Riot Grrrls, a sassy new breed of feminists for the MTV age', Newsweek, 23 November 1992, pp. 884-86, here p. 84.

${ }^{45} L A$ Weekly published an article on Bikini Kill's refusal to engage with the press, including a photograph of Hanna hiding her face from the camera. LA Weekly, 9-15 October 1992, p. 58.
} 
When the movement began to morph and diversify (around 1995), media reports attributed its 'failure' to internal schisms. A brief look at early twenty-first-century mainstream female recording artists in the US, however, reveals how punk characteristics, and in many cases the very term riot grrrl or grrrl, began to be appropriated in a mid-1990s postfeminist climate by corporate institutions in order to market, but also contain, a neutralised, apolitical form of female protest culture. As Dylan Siegler wrote in an introduction to his interview with Kathleen Hanna in 2000, 'an era of thriving musical experimentation and underground rock has come and gone, extinct largely because a music industry Grendel sank in his teeth and shook every indie scene until its neck snapped. Riot grrrl was no exception'. ${ }^{46}$

While riot grrrl bands like Bikini Kill, Bratmobile and Huggy Bear operated exclusively with small independent record labels, artists like The Spice Girls with their brand of 'girl power' in the UK, and in the US Avril Lavigne, Pink, Gwen Stefani and the band The Donnas, amongst others, were signed to major mainstream record labels. All of the latter-day artists mentioned above are regularly linked in the press with the labels 'punk', or 'pop punk' or 'grrrl' ${ }^{47}$ Yet, as Anna Feigenbaum argues in her assessment of these post-riot grrrl artists, the economics of production have everything to do with the politics of the product, as 'both the punk and feminist movements have historically been grassroots, locally organised endeavours' and as such 'their emergence as "popular" may render them apolitical or already co-opted' ${ }^{48}$ In the early 1990 s, riot grrrl remained ideologically opposed to capitalism and corporate consumer culture as channels through which dominant oppressive power networks

\footnotetext{
${ }^{46}$ Dylan Siegler, Ms magazine, September (2000), 86-88 (p. 84).

47 'Avril Lavigne: Riot Girl', in the Independent, 22 May 2004, at www.independent.co.uk/artsentertainment/music/features/avril-lavigne-riot-girl-6169362.html (viewed 3 October 2013); 'Gwen Stefani: Material Grrrl', Beauty Riot.com, at www.beautyriot.com/fashion/gwen-stefani-style-evolution-g6362-page3 (viewed 22 August 2013); 'Shy and retiring Pink (yeah, right) is a pop punk party animal', 4Music.com, at www.4music.com/artists/32/Pink (viewed 19 October 2013). The Spice Girls' catchphrase 'girl power' was originally used in a zine created by Kathleen Hanna.

${ }^{48}$ Anna Feigenbaum, 'Remapping the Resonances of Riot Grrrl: Feminisms, Postfeminisms, and "Processes" of Punk', in Yvonne Tasker and Dianne Negra (eds), Interrogating Postfeminism: Gender and the Politics of Popular Culture, Durham and London: Duke University Press, 2007, p. 138.
} 
operated. These popular contemporary artists on the other hand represent what Feigenbaum calls 'corporate packaged girl power that morphed out of Riot Grrrl's success' ${ }^{49}$

Pink is the only one of the mainstream 'punk' artists mentioned above who selfidentifies publicly as feminist. The others operate in either ignorance of the term (Lavigne) or employ alternative descriptors, such as the gynocentric term 'pro-woman' (Stefani), or the neoliberal by-word 'self-empowerment' (The Spice Girls). All of them have taken part in multi-million-dollar advertising campaigns for the beauty industry or have launched their own line of products. Lavigne is linked with Sony, whose products appear regularly in her videos, as well as her own perfume range; Stefani has undertaken advertising campaigns for L'Oreal and Pink for CoverGirl; The Donnas have recorded advertisements for Levis and Pantene. The Spice Girls, famously, launched a lucrative range of dolls representing each band member and famously name-checked the Wonderbra in one of their songs.

Thus, gathered together under the undifferentiated label 'punk', these artists' transgressive qualities become reduced to the trope of sexual and aesthetic transgressiveness (hair colour or fashion sense) — especially in the mainstream visual media of video, television and live performances — and are thereby contained, regardless of the actual content of their songs. Redirected to the realm of physical appearance (white, conventionally pretty) and sexuality (heterosexual, available and sex-positive), pop-punk transgressiveness becomes a vehicle for the marketing and sale of products to young women, an observation supported by the type of advertising these young women become linked with, and a non-threatening source of sexual fantasy for a heterosexual male audience. As Ariel Levy observes in her influential work Female Chauvinist Pigs: '[t]he glossy, overheated thumping of sexuality in our culture is less about connection than consumption. Hotness has become our cultural currency, and a lot of people spend a lot of time and a lot of regular, green currency trying to acquire it. [...]

\footnotetext{
${ }^{49}$ Feigenbaum, 'Remapping the Resonances of Riot Grrrl', p. 139.
} 
Hot can mean popular. Hot can mean talked about. But when it pertains to women, hot means two things in particular: fuckable and salable [sic]. ${ }^{50}$ So when Avril Lavigne sings 'I don't care about my makeup/I like it better with my jeans all ripped up/Don't know how to keep my mouth shut/[...] Let's get wasted', her superficially transgressive gesture is absorbed and made meaningless by the politically neutralised, sexualised context in which she operates, i.e. corporate consumer culture which is driven by an ideal of conspicuous, raunchy female sexuality. ${ }^{51}$ As Feigenbaum notes, 'the pathways of capital $[\ldots]$ inform and produce any feminist politics that is subsumed' in the artistic performances of these individuals. ${ }^{52}$

In her insightful work Girls (2002), Catherine Driscoll asks whether feminism can be a 'mass-produced, globally distributed product' and whether 'merchandized relations to girls' can be authentic. ${ }^{53}$ In other words, can a product of capitalism critique capitalism in good faith? And can consumers of that product genuinely step outside the capitalist framework to understand that critique? In one of her spoken-word poems, Hanna provides a quote by Morgan Star taken from the literary journal Sinister Wisdom: ' $[\mathrm{t}]$ he more a system expands to include what looks like change but essentially isn't, the harder it is to stand outside that system and criticize it. ${ }^{, 54}$ When, in 2004, Hanna's band Le Tigre signed with the mainstream corporation Universal Records, many riot grrrls felt that the movement, in the form of one of its originators, had finally been fully absorbed by the capitalist system. Yet, the band argued that availing themselves of mainstream, corporate resources ensured the dissemination of radical feminist protest on a larger scale. Band member Johanna Fateman told reporters:

\footnotetext{
${ }^{50}$ Ariel Levy, Female Chauvinist Pigs: Women and the Rise of Raunch Culture, New York and London: Free Press, 2005, p. 31.

${ }^{51}$ Avril Lavigne, 'Rock and Roll', 2013.

${ }^{52}$ Feigenbaum, 'Remapping the Resonances of Riot Grrrl', p. 140.

${ }^{53}$ Catherine Driscoll, Girls: Feminine Adolescence in Popular Culture and Cultural Theory, New York: Columbia University Press, 2002, p. 272.

${ }^{54}$ Fales Library and Special Collections, New York University Libraries: Kathleen Hanna Papers, MSS 271, box 2, folder 2, Hanna, unnamed spoken-word fragment, date unknown.
} 
' $[\mathrm{t}]$ here were no feminist voices at all in the mainstream and we felt like it would be really great if we could have some kind of a presence to a larger audience. 55

\section{Riot Grrrl on the Screen: The Commodification of Feminist Forums}

By the close of the 1990s, the riot grrrl ethos, far from being extinguished, had found renewed expression on the Internet, through an interactive subculture capable of avoiding the surveillance structures of the physical world and reaching a wider, younger audience.

Feigenbaum uses the model of Deleuze and Guattari's rhizome to depict the non-linear pathways and networks first established by riot grrrl zine culture and adopted by what she calls 'Web Gurls'. ${ }^{56}$ Riot grrrl Rebecca Odes, along with Esther Drill and Heather McDonald, founded www.gurl.com in 1996, the largest website dedicated to teenage girls in the US at the time. Since that time, feminist-defined websites for young women and teenagers created and moderated by women in the US have multiplied exponentially. Gurl.com still exists, as do the newer sites for teenage feminists the f bomb and rookie, conceived, produced and moderated by two women under the age of twenty (Julie Zeilinger and Tavi Gevinson). These sites proclaim their feminist credentials to varying degrees, with a greater or lesser focus on fashion and beauty, but all pivot upon the notion of providing young women with a voice in a safe and interactive community forum and a progressive framework for navigating the realm of popular culture. The f bomb's creator introduces the site as:

a blog/community created by and for teenage girls who care about their rights as women and want to be heard. In this case the "F Bomb" stands for "feminist." However, it also pokes fun at the idea that the term "feminist" is so stigmatized-it is our way of proudly reclaiming the word. [...] The FBomb.org is for girls who have enough social awareness to be angry and who want to verbalize that feeling. ${ }^{57}$

Websites for 'older' younger women include Jezebel, Bitch Media, Bust, Feministing and Shakesville, which generally contain greater political content. Bitch and Bust began as

\footnotetext{
55 'Le Tigre Talks Song-Writing, Politics and Spin Magazine', Huntington News, 24 October 2004, at huntnewsnu.com/2004/10/le-tigre-talks-song-writing-politics-and-spin-magazine/ (viewed 19 December 2013).

${ }^{56}$ Feigenbaum, 'Remapping the Resonances of Riot Grrrl', p. 144.

${ }^{57}$ Julie Zeilinger, The f bomb, 2014, at thefbomb.org/about/ (viewed 4 October 2013).
} 
magazines at the height of riot grrrl renown (in 1996 and 1993 respectively) with the aim of providing and encouraging an 'engaged, thoughtful feminist response to mainstream media and popular culture' ${ }^{58}$ The Bitch Media website claims that it attracts over 9,000 views a day and that the magazine has over 10,000 subscribers in over 46 countries. Bitch is a non-profit feminist media organisation and Bust, which is not, nevertheless donates a percentage of its profits to breast cancer research. ${ }^{59}$ Of all of these sites, Feministing and Shakesville are the only ones without an online shop, in which products branded with the online community's logo can be purchased, or where related clothing and beauty products can be viewed from mainstream and/or independent fashion lines. Bust claims to provide 'an uncensored view on the female experience' and to tell the 'truth about women's lives', presenting a 'female perspective on pop-culture' by 'busting stereotypes about women' ${ }^{60}$ However, the page welcoming prospective advertisers reads:

Since 1993, BUST has been the groundbreaking [sic], award-winning, and original women's lifestyle brand that is unique in its ability to truly connect with over half a million members of the $\mathrm{X}$ and $\mathrm{Y}$ generations of female tastemakers. BUST's brand value offers great integrated marketing platforms to strengthen your company's promotional strategies and add to your consumer base. ${ }^{61}$

Jessica Valenti, founder and executive producer of Feministing.com, wrote in 2007 of her love of Bitch and Bust. She locates these magazines and websites in the context of third-wave feminism, wherein she also situates riot grrrl and, in particular, Kathleen Hanna, 'scrawling SLUT across her stomach' ${ }^{62}$ Valenti's Full Frontal Feminism must be viewed against the backdrop of a growing body of online feminist work, previously discussed, which claims that young women can engage with popular culture in a self-reflexive, critical manner and can locate a scene of agency in their negotiations without being duped by corporate consumer

\footnotetext{
58 'About Us', Bitch Media, 2013, at bitchmagazine.org/about-us (viewed 3 October 2013).

59 'Bust Boobtique', Bust, 2013, at www.bustboobtique.com/ (viewed 3 October 2013).

60 'About Bust', Bust, 2013, at www.bust.com/info/about-bust.html (viewed 2 October 2013).

61 'Advertise with Bust', Bust, 2013, at www.bust.com/advertise-in-bust.html (viewed 2 October 2013).

${ }^{62}$ Jessica Valenti, Full Frontal Feminism: A Young Woman's Guide to Why Feminism Matters, Berkeley, CA: Seal Press, 2007, p. 173.
} 
culture. Valenti states, for example: 'I do have faith that younger women can look at pop culture and analyse it in a way that's positive'. ${ }^{63}$

However, some of these communities, such as Bust above, translate feminism into a 'lifestyle brand' - a move that riot grrrl never condoned - thus handing it over wholesale to market forces. This interaction cynically transforms a feminist community, which promises its members - in bad faith - a toolkit for negotiating pop-culture to their advantage, into a marketing platform from which young women are offered up as consumers-in-waiting. As the advertisements these young women view emanate from a trusted, feminist source, they appear endorsed by community, acceptable and desirable. The profits gained by the site allegedly flow back into the running of the community, but this process is not transparent, and the cycle continues. When Valenti advises young women not to 'believe the hype' when encountering pop-culture, urging them: 'roll your eyes when you see a sexist ad and point out its bullshittery [sic] to everyone around you', she overlooks the more insidious ways in which elements of pop-feminist media collude with corporate consumer culture to produce - and profit from-young women's desires. ${ }^{64}$ It is perhaps worth recalling Angela McRobbie's work on young women's melancholia and illegible rage at this point. She contends that subcultural entities like riot grrrl, the f word and Ladyfest provide young women with the opportunity to overcome melancholia by 're-attaching to social life' and to detach from the 'self-berating ego' coterminous with illegible rage. ${ }^{65}$ But she also observes that no market is 'more precious to contemporary capitalism and its consumer culture than that of young women' ${ }^{66}$ Subcultures are 'almost instantly tracked, charted, documented and publicised',

\footnotetext{
${ }^{63}$ Valenti, Full Frontal Feminism, p. 43.

${ }^{64}$ Valenti, Full Frontal Feminism, p. 239.

${ }^{65}$ Angela McRobbie, The Aftermath of Feminism: Gender, Culture and Social Change, Los Angeles and London: Sage, 2009, p. 121.

${ }^{66}$ McRobbie, The Aftermath of Feminism, p. 121.
} 
which process, alongside 'incessant discourses of female individualisation', transforms subcultures into spaces where young women's rage becomes 'once again illegible'. ${ }^{67}$

The Twitter campaign of August 2013 entitled ‘Solidarity is for White Women’ and online responses to Courtney Martin and Vanessa Valenti’s 2012 report on the future of online feminism represented a welcome challenge to what various online feminists call 'Anglo Centric' online feminism, a seemingly deterritorialised, neutral zone which is in fact white and US centric. ${ }^{68}$ These voices remain radical, staunchly opposed to cultural 'assimilation', staunchly resistant to mainstream feminism, which as one commentator puts it in relation to the UK is 'once again, Caitlin Moran'. ${ }^{69}$ It is from these quarters that continued feminist resistance to corporate consumer culture emerges.

This article traced the development of the transgressive feminist gesture in riot grrrl textual productions, identifying at least one important source of literary influence in the form of Kathy Acker's postmodern feminist fiction. This transmission across time, social groups and media spread the articulation of transgressive disruption to the underground music scene and grass-roots literary exchange. However, its entry into the mainstream music scene resulted in the co-option of the female transgressive gesture by commercial forces and its consequent redeployment as a sexualised and depoliticised marketing tool. Finally, I demonstrated how cultural shifts, namely the mainstream commercialisation of local and/or radical feminist engagement, entail that an originally subversive gesture begins to signify in different, increasingly normative ways on the stage, the page, or indeed the computer screen.

\section{Works Cited}

\section{Manuscripts}

\footnotetext{
${ }^{67}$ McRobbie, The Aftermath of Feminism, p. 121.

${ }^{68}$ Mikki Kendall, '\#SolidarityIsForWhiteWomen: Women of Colour's Issue with Digital Feminism', Guardian, 14 August 2013. Courtney E. Martin and Vanessa Valenti, '\#FemFuture: Online Feminism', New Feminist Solutions, 8: 1, 2012, 1-34.

${ }^{69}$ Flavia Dzodan, 'US Centrism and Inhabiting a Non-Space in \#femfuture', Red Light Politics, 10 April 2013 , at www.redlightpolitics.info/post/47611939840/us-centrism-and-inhabiting-a-non-space-in-femfuture (viewed 5 October 2013).
} 
New York, Fales Library and Special Collections, New York University Libraries: Ramdasha Bikceem Riot Grrrl Collection, MSS 354, box 5, folder 23. Bikceem, GUNK \#4, 1993

New York, Fales Library and Special Collections, New York University Libraries: Johanna Fateman Riot Grrrl Collection, MSS 258, box 1, folder 64

- Kathleen Hanna, April Fools’ Day, 1995

- Kathleen Hanna, 'When the Words that once Liberated You Become Bars on Yr Cage random notes on political depression'

- Kathleen Hanna, 'POSTMODERNIST DISCOURSE AS TRANSMUTATED THRU THE TELEVISION'

New York, Fales Library and Special Collections, New York University Libraries: Zan Gibbs Riot Grrrl Zine Collection, MSS 364, box 1, folder 20. Sheila Heti, Brillantine, approx. 1996

New York, Fales Library and Special Collections, New York University Libraries: Kathleen Hanna Papers, MSS 271, box 1, folder 25. Kathleen Hanna, un-named prose piece, date unknown

- Kathleen Hanna, 'Essay' and 'Customers', date unknown

New York, Fales Library and Special Collections, New York University Libraries: Kathleen Hanna Papers, MSS 271, box 2, folder 2. Kathleen Hanna, unnamed spoken-word fragment, date unknown

New York, Fales Library and Special Collections, New York University Libraries: Sheila Heti Riot Grrrl Collection, MSS 366, box 5, folder 8. Heti et al. Poised: An Anthology of Writing and Art by Young Women, 1996

New York, Fales Library and Special Collections, New York University Libraries: Lucy Thane Riot Grrrl Collection, MSS 287, 287.0027 (media). Kathleen Hanna interview, 13 March 1993

\section{Secondary Sources}

'A movement begins in a million pink bedrooms' (1992), LA Weekly, 10-16 July, pp. 19-28. Ablaze!, Karren (2013), 'Riot grrrl: Searching for Music's Young Female Revolutionaries', Guardian, 18 March.

Acker, Kathy (1984), Great Expectations, in Acker, Blood and Guts in High School:Plus Two, London: Picador. (1986), Don Quixote: Which Was a Dream, London: Paladin. 
'Avril Lavigne: Riot Girl' (2004), in the Independent, 22 May, at www.independent.co.uk/arts-entertainment/music/features/avril-lavigne-riot-girl6169362.html (viewed 3 October 2013).

Berlant, Lauren Gail (2008), The Female Complaint: The Unfinished Business of Sentimentality in American Culture, Durham, N. C. and London: Duke University Press.

Bitch Media (2013), at bitchmagazine.org/about-us (viewed 3 October 2013).

Bourdieu, Pierre (1984), Distinction: A Social Critique of the Judgement of Taste, London: Routledge \& Kegan Paul.

Bust (2013), at www.bust.com/info/about-bust.html (viewed 2 October 2013).

Butler, Judith (2006), Gender Trouble: Feminism and the Subversion of Identity, 3 edn, New York and London: Routledge.

Carr, C. (2002),'The Legacy of Kathy Acker, Theoretical Grrrl’, Village Voice, 5 November, p. 49.

Driscoll, Catherine (2002), Girls: Feminine Adolescence in Popular Culture and Cultural Theory, New York: Columbia University Press.

Dzodan, Flavia (2013), 'US Centrism and Inhabiting a Non-Space in \#femfuture', Red Light Politics, 10 April, at www.redlightpolitics.info/post/47611939840/us-centrism-andinhabiting-a-non-space-in-femfuture (viewed 5 October 2013).

Feigenbaum, Anna (2007), 'Remapping the Resonances of Riot Grrrl: Feminisms, Postfeminisms, and 'Processes" of Punk', in Yvonne Tasker and Dianne Negra (eds), Interrogating Postfeminism: Gender and the Politics of Popular Culture, Durham and London: Duke University Press.

Fuss, Diana (1990), Essentially Speaking: Feminism, Nature and Difference, London: Routledge.

'Gwen Stefani: Material Grrrl' (2011), Beauty Riot.com, at www.beautyriot.com/fashion/gwen-stefani-style-evolution-g6362-page3 (viewed 22 August 2013).

Ihle, Christian (2011), 'Who’s That Grrrl? Eine Einleitung zu Riot Grrrl Revisited', taz.blog, 2 November, at blogs.taz.de/popblog/2011/11/02/whos_that_grrrl__eine_einleitung_zu_riot_grrrl_revisited/ (accessed 4 October 2013).

Kendall, Mikki (2013), ‘\#SolidarityIsForWhiteWomen: Women of Colour’s Issue with Digital Feminism', Guardian, 14 August.

Laing, Olivia (2013), 'Grrrls Who Wanted More than Just Fun...', Observer, 30 June. 
Layton, Lynne (1995), 'Trauma, Gender Identity and Sexuality: Discourses of Fragmentation', American Imago, 52: 1, 107-25.

'Le Tigre Talks Song-Writing, Politics and Spin Magazine' (2004), Huntington News, 24

October, at

huntnewsnu.com/2004/10/le-tigre-talks-song-writing-politics-and-spin-magazine/ (viewed 19 December 2013).

Levy, Ariel (2005), Female Chauvinist Pigs: Women and the Rise of Raunch Culture, New York and London: Free Press.

Martin, Courtney E. and Vanessa Valenti (2012), ‘\#FemFuture: Online Feminism', New Feminist Solutions, 8: 1, 1-34.

'Meet the Riot Grrrls, a sassy new breed of feminists for the MTV age' (1992), Newsweek, 23 November, pp. 884-86.

McRobbie, Angela (2009), The Aftermath of Feminism: Gender, Culture and Social Change, Los Angeles and London: Sage.

Peglow, Katja, and Jonas Engelmann (eds) (2011), Riot Grrrl Revisited: Geschichte und Gegewart einer feministischen Bewegung, Mainz: Ventil Verlag.

Pompeo, Joe (2013), 'Original "riot grrrl” Kathleen Hanna meets the press, and this time it's happy', Capital New York, 31 May.

'Shy and retiring Pink (yeah, right) is a pop punk party animal', 4Music.com, at www.4music.com/artists/32/Pink (viewed 19 October 2013).

Siegler, Dylan (2000), Ms magazine, September, pp. 86-88.

Smith, Rachel (2011), 'Revolution Grrrl Style, 20 years later', NPR music, 22 September, at www.npr.org/blogs/therecord/2011/09/20/140640502/revolution-girl-style-20-yearslater? $\mathrm{sc}=\mathrm{tw} \& \mathrm{cc}=\mathrm{share}($ viewed 4 October 2013).

Thi Nguyen, Mimi (2012), 'Riot Grrrl, Race, and Revival', Women and Performance, 22: 23, 173-96.

Valenti, Jessica (2007), Full Frontal Feminism: A Young Woman's Guide to Why Feminism Matters, Berkeley, CA: Seal Press.

Zeilinger, Julie (2014), The f bomb, at thefbomb.org/about/ (viewed 4 October 2013). 